Dr. W. E. Grimshaw, O.B.E.

THE Research Department, Woolwich, has suffered a serious loss through the untimely death of Dr. W. E. Grimshaw, deputy director of ballistics research, at the age of fifty-eight years.

Dr. Grimshaw originally joined the department in 1916 as an assistant proof and experimental officer, remaining at Woolwich until September 1919, and then left to resume his pre-War employment as one of His Majesty's inspectors under the Board of Education. $\mathrm{H}_{e}$ rejoined in 1921 and at once took a leading part in the investigations into fundamental ballistic problems which had, of necessity, to be kept in abeyance during the War period. For this work he was peculiarly fitted as he could combine his wide knowledge of mathematics and physics with the practical artillery experience gained during his War service.

A long series of researches, experimental and theoretical, on the burning of propellants in a closed vessel culminated in the joint publication with $\mathrm{Dr}$. A. D. Crow of two important papers, "The Equation of State of Propellant Gases", (Phil. Trans. Roy. Soc., A, 230 ; 1931) and "The Combustion of Colloidal Propellants" (Phil. Trans., 230; 1932). The first paper greatly extended Petavel's early work on the subject (Phil. Trans. Roy. Soc., A, 205; 1905) while the second put forward the theory that the rate of burning of a propellant (such as service cordite) is conditioned by the density of the surrounding gases rather than by their pressure (Cf. Mansell, Phil. Trans. Roy. אoc., A, 207; 1908). The mathematical consequences of this theory as applied to internal ballistics were examined in two further papers, with Dr. Crow, on "The Combustion Problem of Internal Ballistics" (Phil. Mag., 15, 529, 729; 1933).

Another problem to which Grimshaw turned his attention was that of the behaviour of plastic metals under stress. The determination of the maximum gas pressure in a gun is a matter of great importance for ordnance design, and the service (crusher-gauge) method is to measure the amount of compression experienced by a small copper cylinder enclosed in a steel container fitted with a piston. This gauge, whilst giving reliable comparative results, is known to record less than the true pressure by amounts which vary with the nature of the gun and propellant employed. Grimshaw examined the problem afresh in his paper "The Plastico-Viscous Deformation of Right Circular Cylinders of Soft Metal under Variable Load Axially Directed" (Phil. Trans. Roy. Soc., A, $233 ; 1934)$, and intended afterwards to make practical use of the theory developed therein. The foregoing papers represent only a portion of his work, as it must be remembered that much of it had, of necessity, to remain secret ; but it may bo said that there was not one of the many and various problems connected with ballistics to which he did not make some contribution.

Grimshaw's earlier career at Oxford had been a brilliant one. A scholar of Corpus Christi, he took first elasses in the Final Honour Schools both of mathematics and of physics, and he was junior and senior mathematical scholar of the University graduating B.A. in 1904 and M.A. in 1907. The degree of D.Sc. was conferred on him in 1936, and he was a foundation fellow of the Institute of Physics. His duties as an inspector of schools gave him no opportunities for research, but he got his chance in later life, although of recent years the burden of administrative work left him little but his leisure time for investigation. He had a very wide knowledge of modern mathematical physics and kept abreast of the times by incessant reading.

To his younger colleagues, Grimshaw was always generous with encouragement and help, and was consulted by them in any difficulty as a matter of course. He will be greatly missed as a most valuable member of the Research Department, and as a very loyal friend.

C. A. C.

\section{Dr. G. H. Carpenter}

The Rev. Dr. George Herbert Carpenter died at Guildford, Surrey, on January 22, at the age of seventy-three years. Born at Peckham in 1865, he was the son of George Carpenter and Phoebe Hooper. His early education was private; later he carried on his studies at King's College, London, and at the Royal College of Science, Dublin. After a period as clerk in the Natural History Museum, South Kensington, he became, in 1888, assistant naturalist at the Dublin Museum. He gave up this post in 1904 on being appointed professor of zoology at the Royal College of Science (Dublin), where he stayed until 1922. On leaving Ireland he became keeper of the Manchester Museum (1923-34). A few years after his return to England he became a deacon of the Church and a priest a year later. He was honorary curate at Christ Church, West Didsbury, from 1926 until 1934 and was transferred to a similar position at St. Augustine's, Broxbourne, from 1935 until 1937. He was editor of the Irish Naturalist for thirty years, secretary of the Royal Zoological Society of Ireland from 1911 until 1919 and afterwards secretary of the Royal Irish Academy.

Most of Carpenter's published work was in connexion with entomology. Of his books, "Insects, their Structure and Life", first published in 1899, is an admirable elementary manual. This was followed by his "Insect Transformation" (1921) and the "Biology of Insects" (1928), both of which are characterized by accuracy and clearness of exposition. He made a special study of the order Collembola and became the leading authority on this group in Great Britain. On the morphological side, he was specially interested in segmentation among arthropods and wrote several papers on this topic which were noteworthy in their day. For a number of years, he was consulting entomologist to the Royal Dublin Society, and in this capacity wrote a series of reports on injurious insects in Ireland. $\mathrm{He}$ was especially interested in the warble fly problem, and on this subject ho contributed valuable papers based on carefully planned experiments.

Carpenter's death removes from our midst a kindly and generous personality. He is survived by his wife and son.
A. D. I. 